\title{
Real Time Face Recognition using Eigenface and Viola-Jones Face Detector
}

\author{
Jacky Efendi", Muhammad Ihsan Zul", Wawan Yunanto ${ }^{\#}$ \\ \# Politeknik Caltex Riau, Jl. Umban Sari No. 1, Pekanbaru, 28265, Indonesia \\ E-mail:jacky13ti@mahasiswa.pcr.ac.id,ihsan@pcr.ac.id,wawan@pcr.ac.id
}

\begin{abstract}
Authentication is the process of verifying one's identity and one of its implementation is in taking attendances in university's lectures. Attendance taking is a very important matter to every academic institution as a way to examine students' performance. Signature based attendance taking can be manipulated, therefore it has problems in verifying the attendance validity. In this final project, a real time eigenface based face recognition is implemented in an application to do attendance taking. The input face image is captured using a webcam. The application itself is built in C\#, utilizing EmguCV library. The application is developed using Visual Studio 2015. Face detection is done with Viola-Jones algorithm. The eigenface method is used to do facial recognition on the detected face image. In this final project, a total of 8 testings are done in different conditions. From the testings, it is found that this application can recognize face images with accuracy as high as $90 \%$ and as low as $6.67 \%$. This solution can be used as an alternative for real time attendance taking in environment with 170 lux light intensity, webcam resolution of $320 \times 240$ pixel, and the subject standing 1 meter away while not wearing spectacles. The average recognition time is $0.18125 \mathrm{~ms}$.
\end{abstract}

Keywords - Authentication; Face Recognition; EmguCV; Eigenface; Attendance; Viola-Jones

\section{INTRODUCTION}

Attendance taking matter is a very important matter for academic institution to check the students' performance. Every institution has their own method to handle this matter. Some institutions opted for simple attendance taking by taking students' signatures manually, this wastes a lot of time [1]. Another problem with signatured based approach is that the students could forge the signature for other students [2].

As a solution to signature based attendance taking, some researches have implemented various techniques to take attendance electronically such as the usage of RFId card [3], fingerprint [2], and face recognition [4].

Face image is the most widely used characteristic by people in recognizing other people [5]. One of the way to do face recognition is by using the eigenface approach. Eigenface is face recognition algorithm based on Principle Component Analysis [6]. Eigenface is one of the simplest and most effective PCA approaches used in face recognition systems [7].

Some research that implemented face recognition have been done before. Reference [8] implemented eigenfacebased face recognition on Android device and achieved the accuracy of $93 \%$ with the distance of $1.6 \mathrm{~m}$. Reference [4] also implemented eigenface based face recognition and achieved an accuracy of $88 \%$.

This paper will discuss about the implementation of eigenface based face recognition, running in real time. The input image will be captured using a webcam. Face detection is done using Viola-Jones face detector. The application is built in $\mathrm{C \#}$ programming language and utilizing the EmguCV library.

\section{THE METHODS}

This section will discuss about the eigenface based face recognition, Viola-Jones face detector and the testing condition.

\section{A. Eigenface}

The word eigenface originated from german "eigenwert" where "eigen" means characteristic and "wert" means value. Eigenface is one of many algorithms used to recognize a feature in a face image. Eigenface is based on Principle Component Analysis (PCA) [6]. The basic concept of recognizing face is by taking unique information about the face in question, then encode it and then compare it with the decode result of previously taken image. In eigenface method, decoding is done by calculating eigenvector and then represent it as a matrix. Eigenvector can also be said as 
the characteristic of the face image, thus the method is named eigenface. The eigenface method was first developed by Matthew Turk and Alex Pentland of Vision and Modelling Group, The Media Laboratory, Massachusetts Institute of Technology in 1987. This method is further improved by Turk and Pentland in 1991. The face image used is a grayscale image [10].

The algorithm begins by creating a column matrix from the face images in the training set. The mean vector from said vector is then calculated [10].

Image matrix $(\Gamma)$ is represented in a set of matrices $(\Gamma 1$, $\Gamma 2, \ldots, \Gamma \mathrm{M})$. Calculate the mean $(\Psi)$ of the image matrix and use the result to calculate eigenvector $(v)$ and eigenvalue $(\lambda)$. The eigenvector is then used to find eigenface value. When a test image (Гnew) is going to be recognized, the same processes are done to the test image ( $\Gamma$ new) to extract eigenvector $(v)$ and eigenvalue $(\lambda)$. Then the eigenface of the test image ( $\Gamma$ new) is calculated. Finally, the test image ( $\Gamma$ new) will be recognized by finding the nearest euclidean distance.

The eigenface calculation steps are as follows [11]:

1) Let $\mathrm{S}$ be a set of every images in training set

$$
S=(\Gamma 1, \Gamma 2, \ldots, \Gamma \mathrm{M})
$$

2) Calculate the mean $(\Psi)$

$$
\Psi=\frac{1}{M} \sum_{n=1}^{M} \Gamma_{n}
$$

3) Find the difference $(\Phi)$ between each training image (Гi) and mean $(\Psi)$

$$
\Phi=\Gamma_{i}-\Psi
$$

4) Calculate the covariance matrix (C)

$$
\begin{gathered}
C=\frac{1}{M} \sum_{n=1}^{M} \Phi_{n} \Phi_{n}^{T} \\
=A A^{T}
\end{gathered}
$$

5) Find eigenvalue $(\lambda)$ and eigenvector (v) using the covariance matrix $(\mathrm{C})$

$$
C v_{i}=\lambda_{i} v_{i}
$$

6) Find weight values $(\mu)$

$$
\begin{aligned}
& \mu_{i}=\sum_{k}^{M} v_{i k} \Phi_{k} \\
& \Omega=\left[\mu_{1}, \mu_{2}, \ldots, \mu_{M}\right]
\end{aligned}
$$

The recognition steps are as follows:

1) Calculate the weight value of the test image by following the 6 steps above.

$$
\begin{array}{r}
\mu_{\text {new }}=v\left(\Gamma_{\text {new }}-\Psi\right) \\
\Omega=\left[\mu_{1}, \mu_{2}, \ldots, \mu_{M}\right]
\end{array}
$$

2) Find the closest euclidean distance between the weight value of the test image to every images in the training set.

$$
\varepsilon_{k}=\left\|\Omega-\Omega_{k}\right\|
$$

If the euclidean distance is higher than a certain threshold, the face will be classified as not recognized.

\section{B. Viola-Jones Face Detector}

In 2001, Viola and Jones developed an object detection algorithm based on haar cascade classifier [5]. In 2004, Viola and Jones further developed this algorithm to detect face image in real time with high performance and accuracy. This algorithm works by finding feature in an image in the form of contrast pattern of adjacent pixels. Viola and Jones then eliminated features that do not contribute enough to determine whether the said image is a face image or not. After more testings, Viola and Jones chose 6060 features which are tested in 38 stages. This features are considered good enough to determine whether an image is a face image or not. The feature selection was done using the AdaBoost algorithm [12].

As an example, in this face image below, a dark-brightdark contrast pattern is found. This is actually one of the most determining feature in the Viola-Jones face detector.
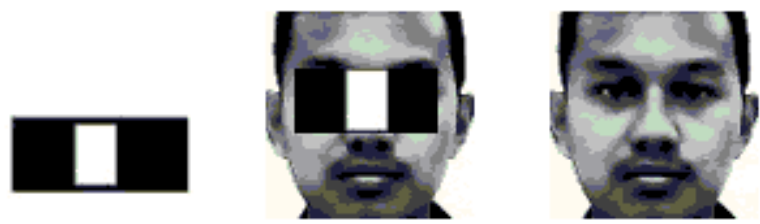

Fig. 1 Example of haar-like feature in an image

The result of Viola and Jones research is a training set that can detect faces in real time with $99 \%$ accuracy. This training set is used as a reference when comparing contrast pattern while doing face detection [12].

\section{ROC Graph}

A receiver operating characteristics (ROC) graph is a technique for visualizing, organizing, and selecting classifiers based [13]. An example of an ROC graph can be seen in figure 2 .

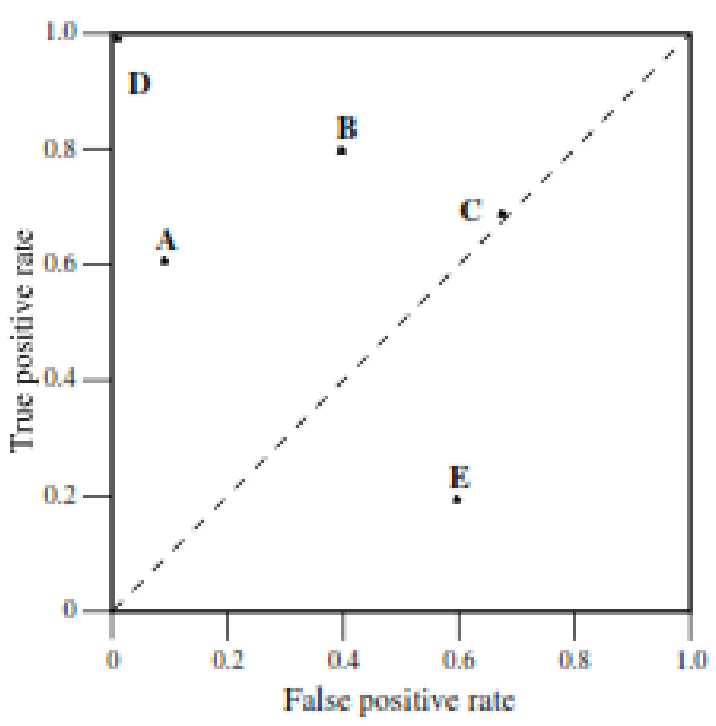

Fig. 2 Example of a ROC graph

\section{Testing Condition}

The training set consists of 60 face images of 10 different subjects taken in a 170 lux room, with a $320 \times 240$ webcam, with the subject standing 1 meter away from the webcam. 6 face images are taken for each of the subjects. 


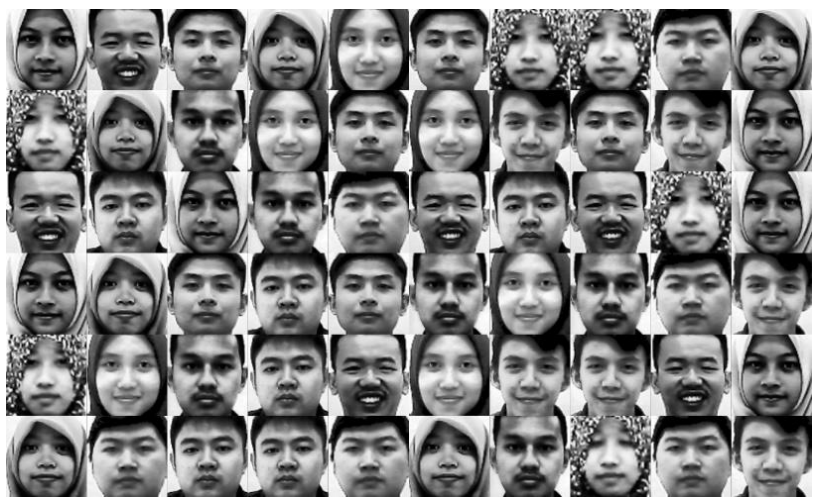

Fig. 3 The face images in the training set

2 testings done, which are, the testing to acquire a threshold value, and testing to measure eigenface based face recognition accuracy in various conditions.

The testing to find the optimal threshold value is done using the testing and training images taken in a 170 lux room, with $320 \times 240$ webcam, with the subject standing 1 meter away from the webcam. The testing images for this test consist of 54 face images of 27 different subjects. 2 face images are taken for each of the subjects.

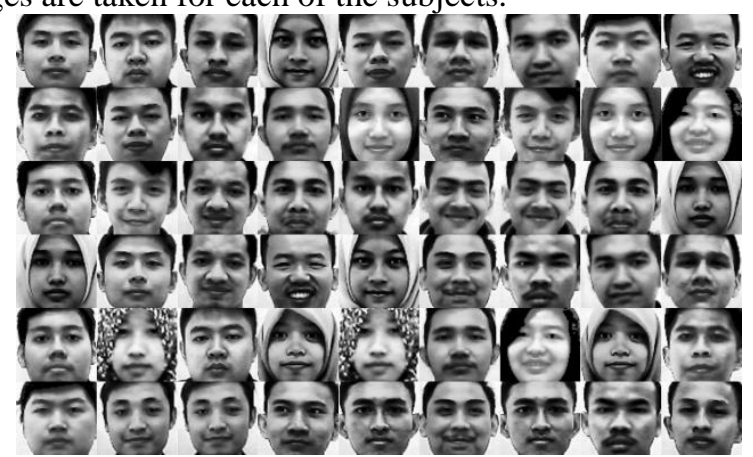

Fig. 4 Testing images for threshold finding

The used threshold value is a factor of the maximum euclidean distance in a given condition as based on previous research [14]. The value acquired will then be used for the testing in various conditions. The conditions of the tests along with the testing images can be seen below:

1) 170 lux room, with a $320 \times 240$ webcam, and subject standing 1 meter away from the webcam

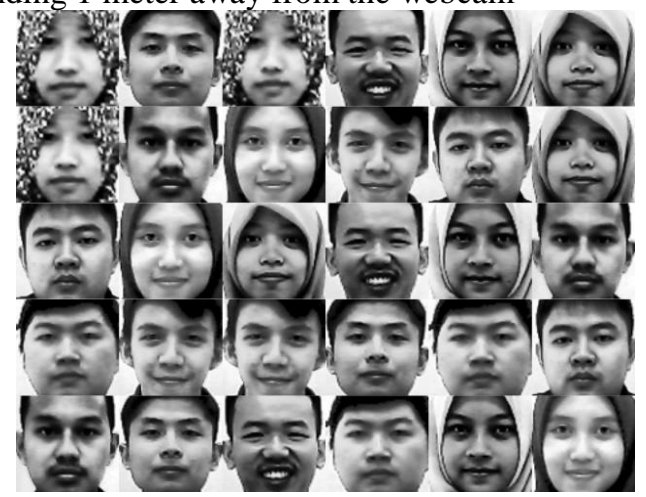

Fig. 5 Testing images for condition 1

2) 130 lux room, with a $320 \times 240$ webcam, and subject standing 1 meter away from the webcam

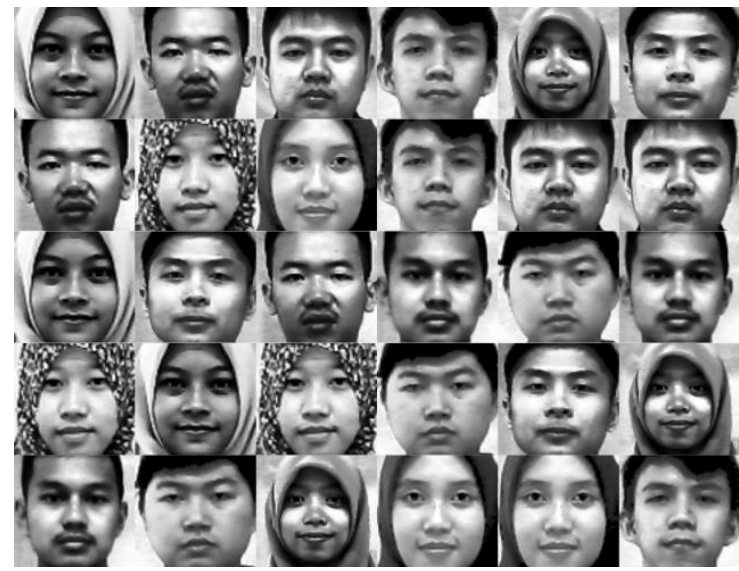

Fig. 6 Testing images for condition 2

3) 100 lux room, with a $320 \times 240$ webcam, and subject standing 1 meter away from the webcam

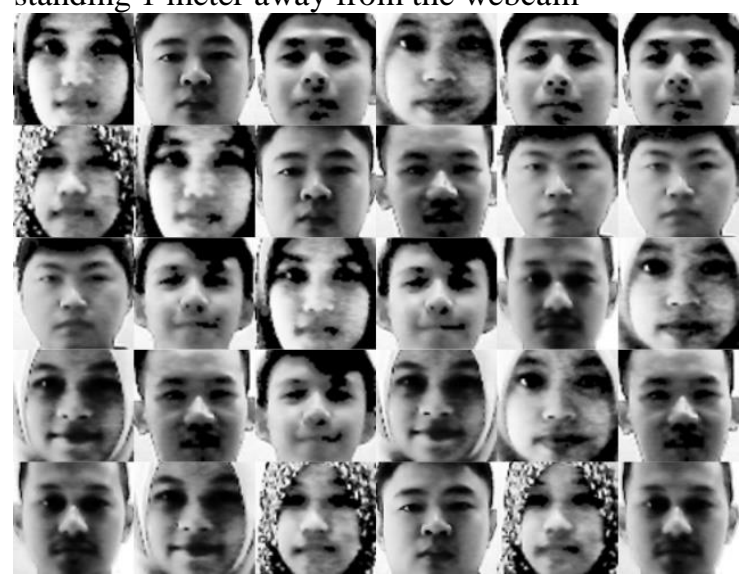

Fig. 7 Testing images for condition 3

4) 170 lux room, with a $320 \times 240$ webcam, and subject standing 2 meter away from the webcam

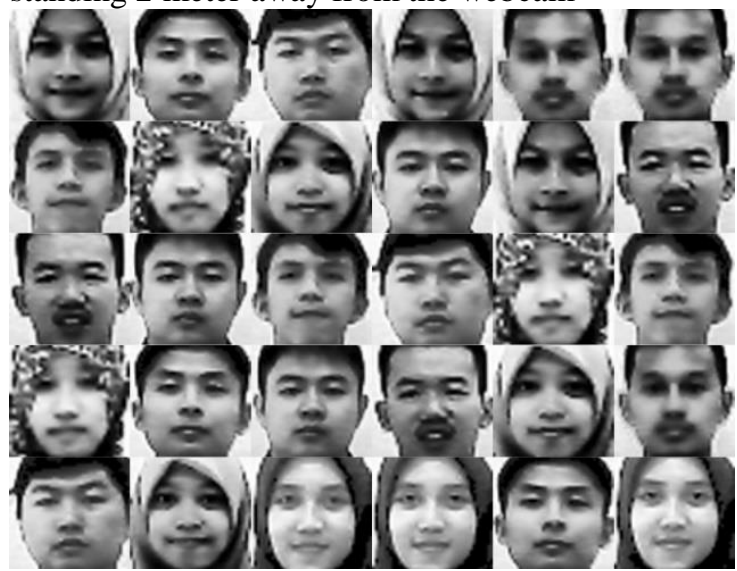

Fig. 8 Testing images for condition 4

5) 170 lux room, with a $320 \times 240$ webcam, and subject standing 3 meter away from the webcam 


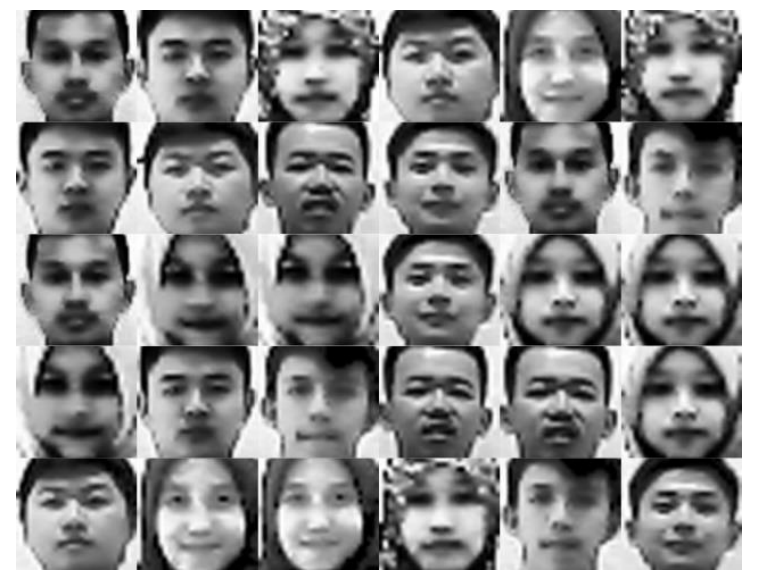

Fig. 9 Testing images for condition 5

6) 170 lux room, with a $240 \times 180$ webcam, and subject standing 1 meters away from the webcam

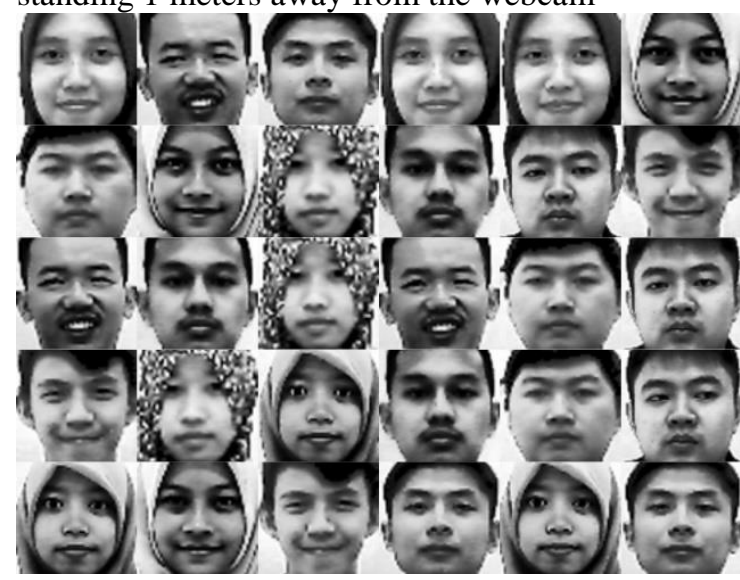

Fig. 10 Testing images for condition 6

7) 170 lux room, with a $160 \times 120$ webcam, and subject standing 1 meters away from the webcam

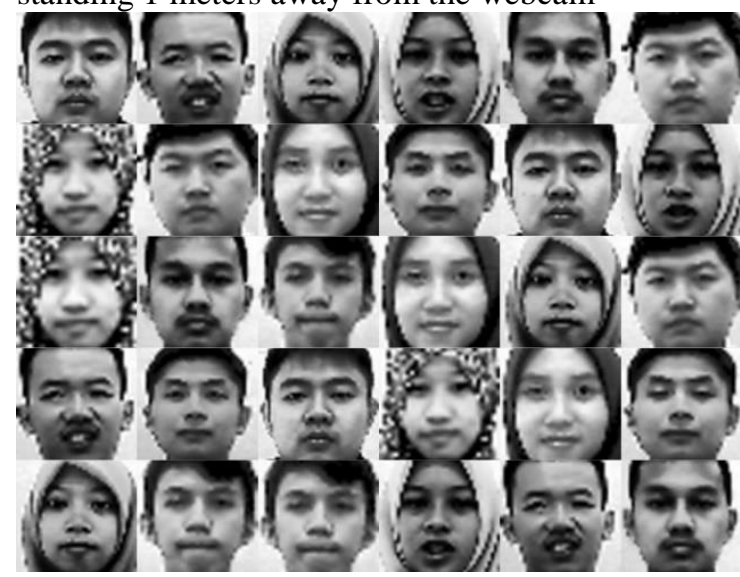

Fig. 11 Testing images for condition 7

8) 170 lux room, with a $320 \times 240$ webcam, and subject standing 1 meter away from the webcam, wearing glasses.

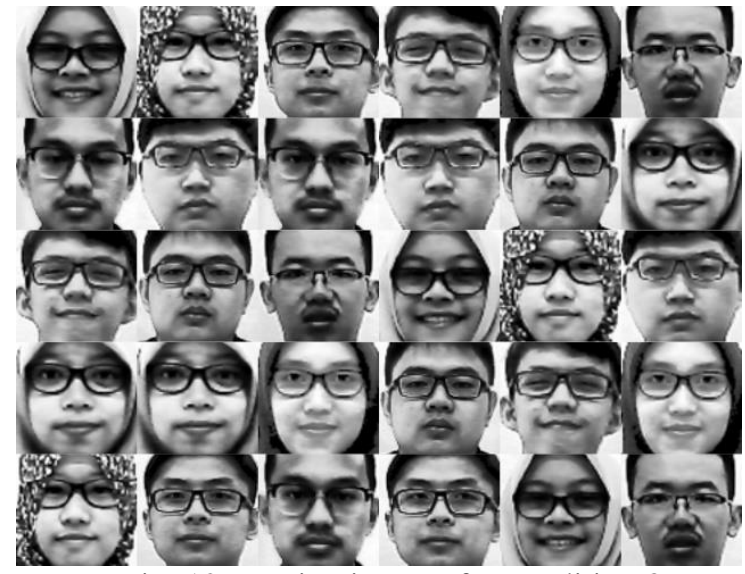

Fig. 12 Testing images for condition 8

\section{RESULTS AND DISCUSSION}

This section will discuss about the findings from the testings done.

\section{A. Threshold Value Testing}

This test is done to acquire the optimal threshold multiplier value to be used in further testing. The testing is done using the ROC curve. The test results can be seen in table I.

TABLE I

Threshold VAlue Test Results

\begin{tabular}{|r|r|r|r|r|r|}
\hline Multiplier & \multicolumn{1}{l|l}{$\begin{array}{l}\text { TP } \\
\text { Rate }\end{array}$} & \multicolumn{1}{l|l}{$\begin{array}{l}\text { RPate } \\
\text { Rensitivity }\end{array}$} & Specifity & $\begin{array}{l}\text { Distance } \\
\text { to (0,1) }\end{array}$ \\
\hline 0.00001 & 0 & 0 & 0 & 1 & 1 \\
\hline 0.0001 & 0.15 & 0 & 0.15 & 1 & 0.85 \\
\hline 0.0005 & 0.3 & 0.0294 & 0.3 & 0.970588 & 0.700618 \\
\hline 0.001 & 0.5 & 0.0588 & 0.5 & 0.941176 & 0.503448 \\
\hline 0.0014 & 0.5 & 0.0882 & 0.5 & 0.911765 & 0.507726 \\
\hline 0.0015 & 0.5 & 0.1176 & 0.5 & 0.882353 & 0.513654 \\
\hline 0.0016 & 0.6 & 0.1176 & 0.6 & 0.882353 & 0.416942 \\
\hline 0.0017 & 0.6 & 0.1176 & 0.6 & 0.882353 & 0.416942 \\
\hline 0.0018 & 0.6 & 0.1176 & 0.6 & 0.882353 & 0.416942 \\
\hline 0.002 & 0.65 & 0.1471 & 0.65 & 0.852941 & 0.37964 \\
\hline 0.0022 & 0.7 & 0.1765 & 0.7 & 0.823529 & 0.348054 \\
\hline 0.0025 & 0.7 & 0.2059 & 0.7 & 0.794118 & 0.363851 \\
\hline 0.0026 & 0.7 & 0.2059 & 0.7 & 0.794118 & 0.363851 \\
\hline 0.003 & 0.7 & 0.2353 & 0.7 & 0.764706 & 0.381265 \\
\hline 0.004 & 0.7 & 0.2353 & 0.7 & 0.764706 & 0.381265 \\
\hline 0.005 & 0.7 & 0.2647 & 0.7 & 0.735294 & 0.400086 \\
\hline 0.0075 & 0.7 & 0.2941 & 0.7 & 0.705882 & 0.420125 \\
\hline 0.01 & 0.8 & 0.3824 & 0.8 & 0.617647 & 0.431502 \\
\hline 0.05 & 1 & 0.8235 & 1 & 0.176471 & 0.823529 \\
\hline 0.1 & 1 & 1 & 1 & 0 & 1 \\
\hline
\end{tabular}

The finding can be represented in a ROC Curve as shown in figure 2. 


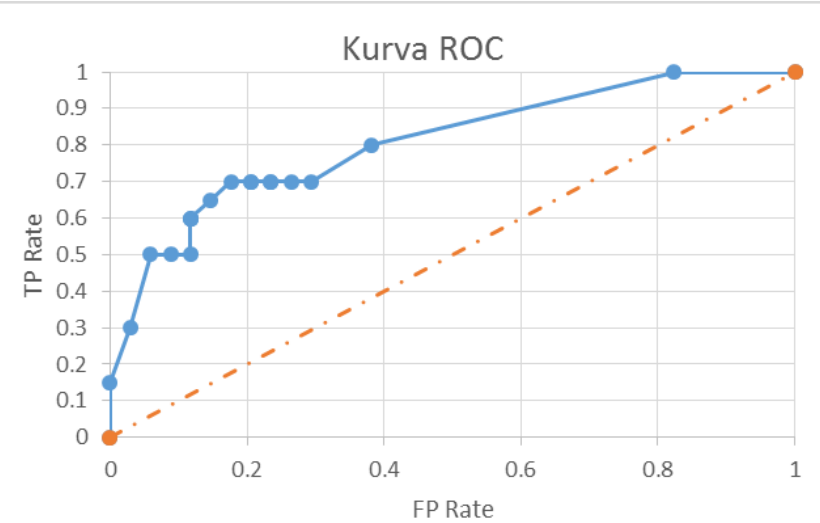

Fig. 13 ROC curve of test results

The blue line represents the tested values. The optimal threshold is the value closest to point $(1,0)$, therefore value 0.0022 is chosen.

\section{B. Face Recognition Testing}

The test results for each conditions can be seen in the following confusion matrices:

1) 170 lux room, with a $320 \times 240$ webcam, and subject standing 1 meter away from the webcam

TABLE II

TEST RESUlTS FOR CONDITION 1

\begin{tabular}{|c|c|c|c|c|c|c|c|c|c|c|c|c|}
\hline \multirow{2}{*}{\multicolumn{2}{|c|}{ Label }} & \multicolumn{11}{|c|}{ Predicted } \\
\hline & & $\mathbf{0}$ & 1 & 2 & 3 & 4 & 5 & 6 & 7 & 8 & 9 & 10 \\
\hline \multirow{11}{*}{ Actual } & $\mathbf{0}$ & 0 & 0 & 0 & 0 & 0 & 0 & 0 & 0 & 0 & 0 & 0 \\
\hline & 1 & 0 & 3 & 0 & 0 & 0 & 0 & 0 & 0 & 0 & 0 & 0 \\
\hline & 2 & 2 & 0 & 1 & 0 & 0 & 0 & 0 & 0 & 0 & 0 & 0 \\
\hline & 3 & 0 & 0 & 0 & 3 & 0 & 0 & 0 & 0 & 0 & 0 & 0 \\
\hline & 4 & 1 & 0 & 0 & 0 & 2 & 0 & 0 & 0 & 0 & 0 & 0 \\
\hline & 5 & 0 & 0 & 0 & 0 & 0 & 3 & 0 & 0 & 0 & 0 & 0 \\
\hline & 6 & 0 & 0 & 0 & 0 & 0 & 0 & 3 & 0 & 0 & 0 & 0 \\
\hline & 7 & 0 & 0 & 0 & 0 & 0 & 0 & 0 & 3 & 0 & 0 & 0 \\
\hline & 8 & 0 & 0 & 0 & 0 & 0 & 0 & 0 & 0 & 3 & 0 & 0 \\
\hline & 9 & 0 & 0 & 0 & 0 & 0 & 0 & 0 & 0 & 0 & 3 & 0 \\
\hline & 10 & 0 & 0 & 0 & 0 & 0 & 0 & 0 & 0 & 0 & 0 & 3 \\
\hline
\end{tabular}

From the first test, the accuracy of eigenface recognition is $90 \%$. The average time of recognition is 176.8 ms.

2) 130 lux room, with a $320 \times 240$ webcam, and subject standing 1 meter away from the webcam

TABLE III

TEST RESUlTS FOR CONDITION 2

\begin{tabular}{|c|c|c|c|c|c|c|c|c|c|c|c|c|}
\hline \multirow{2}{*}{\multicolumn{2}{|c|}{ Label }} & \multicolumn{11}{|c|}{ Predicted } \\
\hline & & $\mathbf{0}$ & 1 & 2 & 3 & 4 & 5 & 6 & 7 & 8 & 9 & 10 \\
\hline \multirow{11}{*}{ Actual } & 0 & 0 & 0 & 0 & 0 & 0 & 0 & 0 & 0 & 0 & 0 & 0 \\
\hline & 1 & 3 & 0 & 0 & 0 & 0 & 0 & 0 & 0 & 0 & 0 & 0 \\
\hline & 2 & 3 & 0 & 0 & 0 & 0 & 0 & 0 & 0 & 0 & 0 & 0 \\
\hline & 3 & 0 & 0 & 0 & 0 & 0 & 0 & 3 & 0 & 0 & 0 & 0 \\
\hline & 4 & 0 & 0 & 0 & 0 & 2 & 0 & 0 & 0 & 1 & 0 & 0 \\
\hline & 5 & 1 & 0 & 0 & 0 & 0 & 2 & 0 & 0 & 0 & 0 & 0 \\
\hline & 6 & 3 & 0 & 0 & 0 & 0 & 0 & 0 & 0 & 0 & 0 & 0 \\
\hline & 7 & 3 & 0 & 0 & 0 & 0 & 0 & 0 & 0 & 0 & 0 & 0 \\
\hline & 8 & 1 & 0 & 0 & 0 & 0 & 0 & 0 & 0 & 2 & 0 & 0 \\
\hline & 9 & 3 & 0 & 0 & 0 & 0 & 0 & 0 & 0 & 0 & 0 & 0 \\
\hline & 10 & 1 & 0 & 0 & 0 & 0 & 1 & 0 & 0 & 0 & 0 & 1 \\
\hline
\end{tabular}

From the second test, the accuracy of eigenface recognition is $23.33 \%$. The average time of recognition is $180.4 \mathrm{~ms}$.

3) 100 lux room, with a $320 \times 240$ webcam, and subject standing 1 meter away from the webcam

TABLE IV

TEST RESUlTS FOR CONDITION 3

\begin{tabular}{|c|c|c|c|c|c|c|c|c|c|c|c|c|}
\hline \multirow{2}{*}{\multicolumn{2}{|c|}{ Label }} & \multicolumn{11}{|c|}{ Predicted } \\
\hline & & $\mathbf{0}$ & 1 & 2 & 3 & 4 & 5 & 6 & 7 & 8 & 9 & 10 \\
\hline \multirow{11}{*}{ Actual } & $\mathbf{0}$ & 0 & 0 & 0 & 0 & 0 & 0 & 0 & 0 & 0 & 0 & 0 \\
\hline & 1 & 3 & 0 & 0 & 0 & 0 & 0 & 0 & 0 & 0 & 0 & 0 \\
\hline & 2 & 2 & 0 & 0 & 0 & 0 & 0 & 1 & 0 & 0 & 0 & 0 \\
\hline & 3 & 0 & 0 & 0 & 1 & 0 & 0 & 2 & 0 & 0 & 0 & 0 \\
\hline & 4 & 3 & 0 & 0 & 0 & 0 & 0 & 0 & 0 & 0 & 0 & 0 \\
\hline & 5 & 2 & 0 & 0 & 0 & 0 & 0 & 0 & 0 & 0 & 0 & 1 \\
\hline & 6 & 3 & 0 & 0 & 0 & 0 & 0 & 0 & 0 & 0 & 0 & 0 \\
\hline & 7 & 2 & 0 & 0 & 0 & 0 & 0 & 0 & 1 & 0 & 0 & 0 \\
\hline & 8 & 3 & 0 & 0 & 0 & 0 & 0 & 0 & 0 & 0 & 0 & 0 \\
\hline & 9 & 3 & 0 & 0 & 0 & 0 & 0 & 0 & 0 & 0 & 0 & 0 \\
\hline & 10 & 3 & 0 & 0 & 0 & 0 & 0 & 0 & 0 & 0 & 0 & 0 \\
\hline
\end{tabular}

From the third test, the accuracy of eigenface recognition is $6.67 \%$. The average time of recognition is $179.6 \mathrm{~ms}$

4) 170 lux room, with a $320 \times 240$ webcam, and subject standing 2 meter away from the webcam

TABLE V

TEST RESUlts FOR CONDITION 4

\begin{tabular}{|c|c|c|c|c|c|c|c|c|c|c|c|c|}
\hline \multicolumn{2}{|c|}{ Label } & \multicolumn{10}{|c|}{ Predicted } \\
\cline { 2 - 13 } & $\mathbf{0}$ & $\mathbf{1}$ & $\mathbf{2}$ & $\mathbf{3}$ & $\mathbf{4}$ & $\mathbf{5}$ & $\mathbf{6}$ & $\mathbf{7}$ & $\mathbf{8}$ & $\mathbf{9}$ & $\mathbf{1 0}$ \\
\hline \multirow{6}{*}{ Actual } & $\mathbf{0}$ & 0 & 0 & 0 & 0 & 0 & 0 & 0 & 0 & 0 & 0 & 0 \\
\cline { 2 - 13 } & $\mathbf{1}$ & 2 & 0 & 0 & 0 & 0 & 0 & 0 & 1 & 0 & 0 & 0 \\
\cline { 2 - 13 } & $\mathbf{2}$ & 3 & 0 & 0 & 0 & 0 & 0 & 0 & 0 & 0 & 0 & 0 \\
\cline { 2 - 13 } & $\mathbf{3}$ & 3 & 0 & 0 & 0 & 0 & 0 & 0 & 0 & 0 & 0 & 0 \\
\cline { 2 - 13 } & $\mathbf{4}$ & 0 & 0 & 0 & 0 & 3 & 0 & 0 & 0 & 0 & 0 & 0 \\
\cline { 2 - 12 } & $\mathbf{5}$ & 3 & 0 & 0 & 0 & 0 & 0 & 0 & 0 & 0 & 0 & 0 \\
\cline { 2 - 12 } & $\mathbf{6}$ & 3 & 0 & 0 & 0 & 0 & 0 & 0 & 0 & 0 & 0 & 0 \\
\cline { 2 - 12 } & $\mathbf{7}$ & 2 & 0 & 0 & 0 & 0 & 0 & 0 & 1 & 0 & 0 & 0 \\
\cline { 2 - 12 } & $\mathbf{8}$ & 2 & 0 & 0 & 0 & 0 & 0 & 0 & 0 & 1 & 0 & 0 \\
\cline { 2 - 12 } & $\mathbf{9}$ & 3 & 0 & 0 & 0 & 0 & 0 & 0 & 0 & 0 & 0 & 0 \\
\cline { 2 - 12 } & $\mathbf{1 0}$ & 3 & 0 & 0 & 0 & 0 & 0 & 0 & 0 & 0 & 0 & 0 \\
\hline
\end{tabular}

From the fourth test, the accuracy of eigenface recognition is $16.67 \%$. The average time of recognition is $184.4 \mathrm{~ms}$.

5) 170 lux room, with a $320 \times 240$ webcam, and subject standing 3 meter away from the webcam

TABLE VI

TEST RESUlTS FOR CONDITION 5

\begin{tabular}{|c|c|c|c|c|c|c|c|c|c|c|c|c|}
\hline \multirow{2}{*}{\multicolumn{2}{|c|}{ Label }} & \multicolumn{11}{|c|}{ Predicted } \\
\hline & & 0 & 1 & 2 & 3 & 4 & 5 & 6 & 7 & 8 & 9 & 10 \\
\hline \multirow{11}{*}{ Actual } & 0 & 0 & 0 & 0 & 0 & 0 & 0 & 0 & 0 & 0 & 0 & 0 \\
\hline & 1 & 1 & 2 & 0 & 0 & 0 & 0 & 0 & 0 & 0 & 0 & 0 \\
\hline & 2 & 3 & 0 & 0 & 0 & 0 & 0 & 0 & 0 & 0 & 0 & 0 \\
\hline & 3 & 1 & 0 & 0 & 2 & 0 & 0 & 0 & 0 & 0 & 0 & 0 \\
\hline & 4 & 3 & 0 & 0 & 0 & 0 & 0 & 0 & 0 & 0 & 0 & 0 \\
\hline & 5 & 3 & 0 & 0 & 0 & 0 & 0 & 0 & 0 & 0 & 0 & 0 \\
\hline & 6 & 2 & 0 & 1 & 0 & 0 & 0 & 0 & 0 & 0 & 0 & 0 \\
\hline & 7 & 3 & 0 & 0 & 0 & 0 & 0 & 0 & 0 & 0 & 0 & 0 \\
\hline & 8 & 2 & 0 & 0 & 0 & 0 & 0 & 0 & 0 & 1 & 0 & 0 \\
\hline & 9 & 3 & 0 & 0 & 0 & 0 & 0 & 0 & 0 & 0 & 0 & 0 \\
\hline & 10 & 2 & 0 & 0 & 0 & 0 & 0 & 0 & 0 & 1 & 0 & 0 \\
\hline
\end{tabular}


From the fifth test, the accuracy of eigenface recognition is $16.67 \%$. The average time of recognition is $177.6 \mathrm{~ms}$.

6) 170 lux room, with a $240 \times 180$ webcam, and subject standing 1 meters away from the webcam

TABLE VII

TEST RESULTS FOR CONDITION 6

\begin{tabular}{|c|c|c|c|c|c|c|c|c|c|c|c|c|}
\hline \multicolumn{2}{|c|}{ Label } & \multicolumn{10}{|c|}{ Predicted } \\
\cline { 2 - 12 } & $\mathbf{0}$ & $\mathbf{1}$ & $\mathbf{2}$ & $\mathbf{3}$ & $\mathbf{4}$ & $\mathbf{5}$ & $\mathbf{6}$ & $\mathbf{7}$ & $\mathbf{8}$ & $\mathbf{9}$ & $\mathbf{1 0}$ \\
\hline \multirow{6}{*}{ Actual } & $\mathbf{0}$ & 0 & 0 & 0 & 0 & 0 & 0 & 0 & 0 & 0 & 0 & 0 \\
\cline { 2 - 12 } & $\mathbf{1}$ & 2 & 1 & 0 & 0 & 0 & 0 & 0 & 0 & 0 & 0 & 0 \\
\cline { 2 - 12 } & $\mathbf{2}$ & 2 & 0 & 1 & 0 & 0 & 0 & 0 & 0 & 0 & 0 & 0 \\
\cline { 2 - 12 } & $\mathbf{3}$ & 1 & 0 & 0 & 0 & 0 & 0 & 2 & 0 & 0 & 0 & 0 \\
\cline { 2 - 12 } & $\mathbf{4}$ & 3 & 0 & 0 & 0 & 0 & 0 & 0 & 0 & 0 & 0 & 0 \\
\cline { 2 - 11 } & $\mathbf{5}$ & 1 & 0 & 0 & 0 & 0 & 1 & 0 & 0 & 0 & 0 & 1 \\
\cline { 2 - 11 } & $\mathbf{6}$ & 1 & 0 & 0 & 1 & 0 & 0 & 1 & 0 & 0 & 0 & 0 \\
\cline { 2 - 11 } & $\mathbf{7}$ & 3 & 0 & 0 & 0 & 0 & 0 & 0 & 0 & 0 & 0 & 0 \\
\cline { 2 - 11 } & $\mathbf{8}$ & 2 & 0 & 0 & 0 & 0 & 0 & 0 & 0 & 1 & 0 & 0 \\
\cline { 2 - 11 } & $\mathbf{9}$ & 3 & 0 & 0 & 0 & 0 & 0 & 0 & 0 & 0 & 0 & 0 \\
\cline { 2 - 11 } & $\mathbf{1 0}$ & 3 & 0 & 0 & 0 & 0 & 0 & 0 & 0 & 0 & 0 & 0 \\
\hline
\end{tabular}

From the sixth test, the accuracy of eigenface recognition is $16.67 \%$. The average time of recognition is $177.3 \mathrm{~ms}$.

7) 170 lux room, with a $160 \times 120$ webcam, and subject standing 1 meters away from the webcam

TABLE VIII

TEST RESULTS FOR CONDITION 7

\begin{tabular}{|c|c|c|c|c|c|c|c|c|c|c|c|c|}
\hline \multicolumn{2}{|c|}{ Label } & \multicolumn{10}{|c|}{ Predicted } \\
\cline { 2 - 12 } & $\mathbf{0}$ & $\mathbf{1}$ & $\mathbf{2}$ & $\mathbf{3}$ & $\mathbf{4}$ & $\mathbf{5}$ & $\mathbf{6}$ & $\mathbf{7}$ & $\mathbf{8}$ & $\mathbf{9}$ & $\mathbf{1 0}$ \\
\hline \multirow{6}{*}{} & $\mathbf{0}$ & 0 & 0 & 0 & 0 & 0 & 0 & 0 & 0 & 0 & 0 & 0 \\
\cline { 2 - 11 } & $\mathbf{1}$ & 2 & 1 & 0 & 0 & 0 & 0 & 0 & 0 & 0 & 0 & 0 \\
\cline { 2 - 11 } & $\mathbf{2}$ & 2 & 0 & 1 & 0 & 0 & 0 & 0 & 0 & 0 & 0 & 0 \\
\cline { 2 - 11 } & $\mathbf{3}$ & 2 & 0 & 0 & 0 & 0 & 0 & 1 & 0 & 0 & 0 & 0 \\
\cline { 2 - 11 } & $\mathbf{4}$ & 3 & 0 & 0 & 0 & 0 & 0 & 0 & 0 & 0 & 0 & 0 \\
\cline { 2 - 11 } & $\mathbf{5}$ & 1 & 0 & 0 & 0 & 1 & 0 & 0 & 0 & 1 & 0 & 0 \\
\cline { 2 - 11 } & $\mathbf{6}$ & 3 & 0 & 0 & 0 & 0 & 0 & 0 & 0 & 0 & 0 & 0 \\
\cline { 2 - 11 } & $\mathbf{7}$ & 3 & 0 & 0 & 0 & 0 & 0 & 0 & 0 & 0 & 0 & 0 \\
\cline { 2 - 11 } & $\mathbf{8}$ & 1 & 0 & 0 & 0 & 0 & 0 & 0 & 0 & 2 & 0 & 0 \\
\cline { 2 - 11 } & $\mathbf{9}$ & 3 & 0 & 0 & 0 & 0 & 0 & 0 & 0 & 0 & 0 & 0 \\
\cline { 2 - 11 } & $\mathbf{1 0}$ & 1 & 0 & 0 & 0 & 0 & 0 & 0 & 0 & 2 & 0 & 0 \\
\hline
\end{tabular}

From the seventh test, the accuracy of eigenface recognition is $13.33 \%$. The average time of recognition is $190.7 \mathrm{~ms}$

8) 170 lux room, with a $320 \times 240$ webcam, and subject standing 1 meter away from the webcam, wearing glasses.

TABLE IX

TEST RESULTS FOR CONDITION 8

\begin{tabular}{|c|c|c|c|c|c|c|c|c|c|c|c|c|}
\hline \multicolumn{2}{|c|}{ Label } & \multicolumn{10}{|c|}{ Predicted } \\
\cline { 2 - 12 } & $\mathbf{0}$ & $\mathbf{1}$ & $\mathbf{2}$ & $\mathbf{3}$ & $\mathbf{4}$ & $\mathbf{5}$ & $\mathbf{6}$ & $\mathbf{7}$ & $\mathbf{8}$ & $\mathbf{9}$ & $\mathbf{1 0}$ \\
\hline \multirow{6}{*}{} & $\mathbf{0}$ & 0 & 0 & 0 & 0 & 0 & 0 & 0 & 0 & 0 & 0 & 0 \\
\cline { 2 - 12 } & $\mathbf{1}$ & 2 & 1 & 0 & 0 & 0 & 0 & 0 & 0 & 0 & 0 & 0 \\
\cline { 2 - 11 } & $\mathbf{2}$ & 3 & 0 & 0 & 0 & 0 & 0 & 0 & 0 & 0 & 0 & 0 \\
\cline { 2 - 11 } & $\mathbf{3}$ & 3 & 0 & 0 & 0 & 0 & 0 & 0 & 0 & 0 & 0 & 0 \\
\cline { 2 - 11 } & $\mathbf{4}$ & 3 & 0 & 0 & 0 & 0 & 0 & 0 & 0 & 0 & 0 & 0 \\
\cline { 2 - 11 } & $\mathbf{5}$ & 1 & 0 & 0 & 0 & 0 & 0 & 0 & 0 & 2 & 0 & 0 \\
\cline { 2 - 11 } & $\mathbf{6}$ & 2 & 0 & 0 & 0 & 0 & 0 & 1 & 0 & 0 & 0 & 0 \\
\cline { 2 - 11 } & $\mathbf{7}$ & 3 & 0 & 0 & 0 & 0 & 0 & 0 & 0 & 0 & 0 & 0 \\
\cline { 2 - 11 } & $\mathbf{8}$ & 3 & 0 & 0 & 0 & 0 & 0 & 0 & 0 & 0 & 0 & 0 \\
\cline { 2 - 11 } & $\mathbf{9}$ & 3 & 0 & 0 & 0 & 0 & 0 & 0 & 0 & 0 & 0 & 0 \\
\cline { 2 - 11 } & $\mathbf{1 0}$ & 1 & 0 & 0 & 0 & 1 & 0 & 0 & 0 & 1 & 0 & 0 \\
\hline
\end{tabular}

From the last test, the accuracy of eigenface recognition is $6.67 \%$. The average time of recognition is $183.2 \mathrm{~ms}$.

The summary of the result can be seen in table X.

TABLE X

FACE RECOGNITION TEST RESUlts

\begin{tabular}{|l|l|l|l|r|c|}
\hline $\begin{array}{l}\text { Light } \\
\text { Intensity }\end{array}$ & Distance & $\begin{array}{l}\text { Webcam } \\
\text { Resolution }\end{array}$ & Glasses & Accuracy & $\begin{array}{l}\text { Average } \\
\text { Time }\end{array}$ \\
\hline 170 lux & $1 \mathrm{~m}$ & $\begin{array}{l}320 \times 240 \\
\text { pixel }\end{array}$ & No & $90 \%$ & $176,8 \mathrm{~ms}$ \\
\hline 130 lux & $1 \mathrm{~m}$ & $\begin{array}{l}320 \times 240 \\
\text { pixel }\end{array}$ & No & $23.33 \%$ & $180,4 \mathrm{~ms}$ \\
\hline 100 lux & $1 \mathrm{~m}$ & $\begin{array}{l}320 \times 240 \\
\text { pixel }\end{array}$ & No & $6.67 \%$ & $179,6 \mathrm{~ms}$ \\
\hline 170 lux & $2 \mathrm{~m}$ & $\begin{array}{l}320 \times 240 \\
\text { pixel }\end{array}$ & No & $16.67 \%$ & $184,4 \mathrm{~ms}$ \\
\hline 170 lux & $3 \mathrm{~m}$ & $\begin{array}{l}320 \times 240 \\
\text { pixel }\end{array}$ & No & $16.67 \%$ & $177,6 \mathrm{~ms}$ \\
\hline 170 lux & $1 \mathrm{~m}$ & $\begin{array}{l}240 \times 180 \\
\text { pixel }\end{array}$ & No & $16.67 \%$ & $177,3 \mathrm{~ms}$ \\
\hline 170 lux & $1 \mathrm{~m}$ & $\begin{array}{l}160 \times 120 \\
\text { pixel }\end{array}$ & No & $13.33 \%$ & $190,7 \mathrm{~ms}$ \\
\hline 170 lux & $1 \mathrm{~m}$ & $\begin{array}{l}320 \times 240 \\
\text { pixel }\end{array}$ & Yes & $6.67 \%$ & $183,2 \mathrm{~ms}$ \\
\hline
\end{tabular}

The tests show that the average time required by the application to recognize a face is $181.25 \mathrm{~ms}$, or 0.18125 second. Since that there is no significant time delay between for each recognition, this shows that eigenface can indeed be used for real time face recognition.

There are a lot of variables that could impact the accuracy of the recognition in a negative way. The darker the environment, the lower the accuracy will be. This can be seen from the test results that show that the accuracy of face recognition in a 130 lux environment and 100 lux environment is $23.33 \%$ and $6.67 \%$, respectively.

The accuracy also goes down when the subject stands further from the webcam and when the resolution of the webcam is reduced. This happens because of the lack of the details able to be captured in those conditions.

The algorithm also failed to recognize the subjects when the subjects wear glasses. This happens because the training set images do not include images of subjects wearing glasses.

The recognition accuracy achieved $90 \%$ only in the same condition as the training condition. This shows that eigenface based face recognition needs a controlled environment to achieve a reasonable accuracy.

\section{CONCLUSIONS}

Usage of eigenface based approach for doing face recognition in a real time system is not a justifiable solution. The test shows that eigenface based face recognition requires a highly controlled environment. Changes in the environment conditions lead to severe drop in accuracy. Therefore, even though eigenface based recognition can recognize faces at a high rate $(0.18125 \mathrm{~ms})$, eigenface based approach still needs a highly controlled environment to be suitable for face recognition in a real time system.

Reference [14] found that the optimal threshold is 0.8 of the maximum euclidean distance, but in our tests we found that the optimal value is 0.0022 . Therefore, it can be concluded that optimal threshold value for eigenface based 
recognition can vary depending on the training image sets and need to be redefined if the training image sets are modified.

\section{NOMENCLATURE}

$\mathrm{V}$ eigenvector

Greek letters

$\Gamma \quad$ image matrix

$\Psi \quad$ mean image

$\Phi \quad$ difference image

$\lambda \quad$ eigenvalue

$\mu \quad$ weight

$\varepsilon \quad$ euclidean distance

\section{ACKNOWLEDGMENT}

We would like to thank all people that supported, either by giving physical or morale support the authors during the process of this research.

\section{REFERENCES}

[1] Balcoh, N. K., Yousaf, M. H., Ahmad, W., \& Baig, M. I. (2012) Algorithm for Efficient Attendance Management: Face Recognition based Approach. IJCSI International Journal of Computer Science Issues, 146-150. (http://www.ijcsi.org/papers/IJCSI-9-4-1-146150.pdf)

[2] Muhammad, N. A. (2013). Pembuatan Aplikasi Presensi Perkuliahan Berbasis Fingerprint (Studi Kasus: Jurusan Sistem Informasi Institut Teknologi Sepuluh Nopember Surabaya). Jurnal Teknik POMITS A465-A469.

(http://ejurnal.its.ac.id/index.php/teknik/article/view/5160/1539)

[3] Setiawan, E. B., \& Kurniawan, B. (2015). Perancangan Sistem Absensi Kehadiran Perkuliahan dengan Menggunakan Radio Frequency Identification (RFId). Jurnal CoreIT, 44-49. (http://ejournal.uin-

suska.ac.id/index.php/coreit/article/download/1228/1108)

[4] Muliawan, M. R. (2015). Implementasi Pengenalan Wajah dengan Metode Eigenface pada Sistem Absensi. Jurnal Coding, Sistem Komputer Untan, 41-50. (http://jurnal.untan.ac.id/index.php/jcskommipa/article/viewFile/972 $\underline{7 / 9500}$

[5] Viola, P., \& Jones, M. (2001). Rapid Object Detection Using a Boosted Cascade of Simple Features. Computer Vision and Pattern Recognition, 511-518. (http://www.merl.com/reports/docs/tr2004043.pdf)

[6] Fatta, H. A. (2006). Sistem Presensi Karyawan Berbasis Pengenalan Wajah dengan Algoritma Eigenface. Yogyakarta: STMIK AMIKOM.

[7] Slavkovic, Marijeta \& Jevtic, Dubravka. (2012). Face Recognition Using Eigenface Approach. Serbian Journal of Electrical Engineering, 9(No. 1), 121-130.

[8] Setiadi, D. (2013). Aplikasi Identifikasi Personal dengan Metode Principle Component Analysis Berbasis Android. Pekanbaru: Politeknik Caltex Riau.

[9] Rahman, M. A. (2010). Sistem Pengenalan Wajah Menggunakan Webcam untuk Absensi dengan Metode Template Matching. Surabaya: Politeknik Negeri (http://repo.pens.ac.id/538/1/949.pdf)

[10] Indra. (2012). Sistem Pengenalan Wajah dengan Metode Eigenface untuk Absensi pada PT. Florindo Lestari. Jakarta: Universitas Budi Luhur.

(http://publikasi.dinus.ac.id/index.php/semantik/article/view/96/59)

[11] Turk, M., \& Pentland, A. (1991). Eigenfaces for Recognition. Journal of Cognitive Neuroscience, 3, 71-86. (http://www.mitpressjournals.org/doi/abs/10.1162/jocn.1991.3.1.71)

[12] Viola, P., \& Jones, M. (2004) Robust Real-Time Face Detection. International Journal of Computer Vision, 137-154. (http://link.springer.com/article/10.1023/B:VISI.0000013087.49260. b)

[13] Fawcett, T. (2006). An Introduction to ROC Analysis. Pattern Recognition Letters, 861-874. (http://people.inf.elte.hu/kiss/11dwhdm/roc.pdf)

[14] Gupta, Sheifali, Sahoo, O. P., Goel, A., \& Gupta, R. (2010) A New Optimized Approach to Face Recognition Using Eigenfaces. Global Journal of Computer Science and Technology, 10, 15-17. (http://computerresearch.org/index.php/computer/article/view/914) 